\title{
PENGEMBANGAN PERANGKAT PEMBELAJARAN IPA TOPIK TEKANAN PADA ZAT CAIR BERORIENTASI INKUIRI TERBIMBING UNTUK MELATIHKAN KETERAMPILAN PROSES SAINS DAN PEMAHAMAN KONSEP SISWA SMP
}

\author{
Rustika Novita Sari' ${ }^{1)}$ Muslimin Ibrahim²), Wasis ${ }^{3)}$ \\ ${ }^{1)}$ Mahasiswa Program Studi Pendidikan Sains, Program Pascasarjana Universitas Negeri Surabaya \\ ${ }^{2), 3)}$ Dosen Pascasarjana Prodi Pendidikan Sains Univesrtitas Negeri Surabaya \\ Email: rustika.ns@gmail.com
}

\begin{abstract}
This research aimed to develop a valid, practical, and effective Science learning material with guided inquiry oriented to facilitate science process skill and science concept understanding of junior high school on the topic of the liquid pressure. The learning materials were developed with four-D model and try outed to the class VIII SMP Negeri 7 Bontang using one-group pretest-posttest design. The results were obtained: 1) The developed teaching materials were valid category with lesson plan scored 3.55, LKS scored 3.63, Student Book scored 3.63, performance test scored 3.43, and understanding concept test scored 3.75; readability of student book had 77,29\% were easy to used for learning category; 2) The learning material is practiced to use in learning activity with score average of learning implementation is 3.6 in good category; 3) The learning material is also effective to facilitate to get science process skill student had high gain scores average with gain score 0.82; understanding of the concepts is also increasing had high category with gain score 0.73 ; the students respons toward material and implementation of learning are positive. The conclusion of the research is Science learning materials on the topic of liquid pressure with guided inquiry orientation are valid, practical, and effective to facilitate science process skill and science concept understanding in junior high school.
\end{abstract}

Keywords: Development of Learning Material, Guided Inquiry, Science Process Skills, Science Concept Understanding

\begin{abstract}
Abstrak: Penelitian ini bertujuan untuk mengembangkan perangkat pembelajaran IPA yang valid, praktis, dan efektif berorientasi model inkuiri terbimbing untuk melatihkan kemampuan proses sains dan pemahaman konsep siswa SMP topik tekanan pada zat cair. Perangkat pembelajaran dikembangkan dengan model 4-D yang diujicobakan kepada siswa kelas VIII SMP Negeri 7 Bontang dengan menggunakan One-Group Pretest-Posttest Design. Hasil penelitian ini menunjukkan: 1) Perangkat pembelajaran yang dikembangkan berkategori valid dengan penilaian pada RPP sebesar 3,55, LKS sebesar 3,61, Buku Siswa sebesar 3,63, tes keterampilan proses sains 3,43, dan tes pemahaman konsep 3,75; tingkat keterbacaan buku siswa sebesar 77,29\% dengan kategori materi mudah untuk pembelajaran; 2) Perangkat pembelajaran yang dihasilkan praktis digunakan dalam pembelajaran yang terlihat dari rata-rata penilaian keterlaksanaan RPP sebesar 3,66 berkategori baik dan aktivitas siswa menunjukkan pembelajaran yang berpusat pada siswa; 3) Perangkat pembelajaran yang dikembangkan efektif untuk melatihkan keterampilan proses sains siswa dengan rata-rata peningkatan berkategori tinggi dengan gain score sebesar 0,82; rata-rata pemahaman konsep siswa juga meningkat dengan kategori tinggi dengan gain score 0,73 ; respon siswa positif terhadap perangkat dan pelaksanaan pembelajaran. Berdasarkan hasil penelitian tersebut, disimpulkan bahwa perangkat pembelajaran IPA topik tekanan pada zat cair berorientasi inkuiri terbimbing yang dikembangkan valid, praktis, dan efektif untuk melatihkan kemampuan proses sains dan pemahaman konsep siswa SMP
\end{abstract}

Kata Kunci: Perangkat Pembelajaran, Inkuiri Terbimbing, Keterampilan Proses Sains, Pemahaman Konsep

\section{PENDAHUluan}

Penyelenggaraan pendidikan sebagaimana yang diamanatkan dalam Undang-undang Nomor 20 Tahun 2003 tentang Sistem Pendidikan Nasional diharapkan dapat mewujudkan proses berkembangnya kualitas pribadi siswa sebagai generasi penerus bangsa di masa depan, yang diyakini akan menjadi faktor yang menentukan bagi tumbuh kembangnya bangsa dan Negara Indonesia sepanjang zaman. Sumber daya manusia berkualitas dihasilkan oleh pendidikan yang berkualitas sehingga menjadi kekuatan utama untuk mengatasi masalah-masalah yang akan dihadapi. Salah satu cara yang ditempuh adalah melalui peningkatan mutu pendidikan. Pendidikan yang baik adalah pendidikan yang dalam kegiatan pembelajaran dirancang untuk memberikan pengalaman belajar yang melibatkan siswa aktif dalam rangka pencapaian pengetahuan.

Guru sebagai praktisi pendidikan berperan langsung dalam merancang proses pembelajaran harus 
melakukan perubahan pembelajaran sesuai dengan perkembangan peserta didik, yaitu dari pembelajaran behavioristik menuju konstruktivistik. Menurut Piaget (dalam Arends, 2013), anak-anak terlahir membawa potensi rasa ingin tahu dan secara terus menerus bekerja keras memahami dunia sekitar. Keingintahuan siswa perlu difasilitasi di dalam pembelajaran sehingga rancangan kegiatan pembelajaran hendaknya dapat mengembangkan potensi siswa menjadi kompetensi melalui belajar secara aktif. Siswa diberi kesempatan secara langsung terlibat dalam aktivitas ilmiah seperti seorang ilmuwan menemukan konsep atau fakta baru untuk membangun pengetahuannya. Siswa diajak melakukan pencarian pengetahuan melalui berbagai aktivitas sains sebagaimana para ilmuwan dalam penyelidikan ilmiah (Nur, 1998). Wenning (2005) menyatakan bahwa peran guru dan siswa berubah, guru tidak lagi sebagai pemasok informasi, melainkan sebagai fasilitator dan pembimbing siswa dalam pembelajaran.

Kegiatan penyelidikan ilmiah oleh siswa dalam pencarian pengetahuan tidaklah mudah tetapi memerlukan suatu keterampilan yang dinamakan keterampilan proses. Semiawan (1990) menyatakan adalah keterampilan proses sains adalah keterampilanketerampilan fisik dan mental untuk menemukan dan mengembangkan sendiri fakta dan konsep sains serta menumbuhkan dan mengembangkan sikap dan nilai yang dituntut. Keterampilan proses sains diklasifikasikan menjadi keterampilan proses dasar dan keterampilan proses terpadu. Melalui keterampilan proses siswa akan berpikir tingkat tinggi, mampu belajar mandiri, mengembangkan diri sendiri dan dengan keterampilan proses siswa telah menguasai keterampilan yang diperlukan dalam berpikir tingkat tinggi yaitu melalui penelitian dan penyelidikan masalah (Ibrahim, 2010).

Hasil penelitian tentang analisis Keterampilan Proses Sains anak-anak Indonesia dibandingkan Negara lain menyebutkan bahwa 78\% Soal Ujian Nasional (UN) mengenai keterampilan proses sains meliputi meramal/memprediksi dan menerapkan konsep, 96\% soal Trends International Mathematics And Science Study (TIMSS) meliputi mengamati, merumuskan hipotesis, meramal/memprediksi, menerapkan konsep dan berkomunikasi, dan 89\% dari Soal Programe For International Student Assessment (PISA) meliputi mengamati, meramal/ memprediksi, menerapkan konsep dan berkomunikasi (Ramadhan dan Wasis, 2013). Nilai rata-rata sains pada tahun 2009 adalah 383, menduduki peringkat ke 66 dari 74 negara peserta PISA. Tahun 2012 nilai rata-rata sains siswa Indonesia menurun menjadi 382 menduduki peringkat ke 64 dari 65 peserta (OECD, 2013). Hasil analisis ini mengindikasikan bahwa keterampilan proses sains siswa masih perlu untuk dilatihkan dalam pembelajaran di sekolah karena IPA berkaitan dengan cara mencari tahu tentang alam secara sistematis melalui proses penemuan. Penelitian Aktamis (2008) juga menyatakan bahwa keterampilan proses ilmiah meningkatkan pemahaman siswa terhadap konsep yang dipelajari dan kreatifitas ilmiah.

Model pembelajaran yang mendukung keterampilan proses sains adalah inkuiri. Menurut Borich dan Choo (2006) pembelajaran inkuiri merupakan pembelajaran pemerolehan melalui proses mencari informasi, pengetahuan dan fakta dengan pertanyaan-pertanyaan Model pembelajaran inkuiri memungkinkan siswa untuk secara aktif menemukan sendiri konsep atau pengetahuan baru melalui proses hands-on activity dan mind-on activity. Siswa yang belum terbiasa menggunakan model inkuiri, maka sebagai pengawal dapat digunakan guided inquiry (inkuiri terbimbing). Inkuiri terbimbing membantu siswa untuk berlatih dalam sebuah tim, mengembangkan kompetensi dalam penelitian, pengetahuan, motivasi, pemahaman bacaan, perkembangan bahasa, kemampuan menulis, pembelajaran kooperatif, dan keterampilan sosial Kuhlthau (2007).

Pelaksanaan kegitatan pembelajaran dengan model inkuiri terbimbing tentunya memerlukan perangkat pembelajaran yang sesuai. Ibrahim (2002) menyatakan bahwa perangkat pembelajaran memberi kemudahan dan dapat membantu guru dalam mempersiapkan dan melaksanakan kegiatan belajar mengajar di kelas untuk mencapai tujuan yang sudah ditentukan. Menurut Nieveen (1999), perangkat pembelajaran yang baik jika memenuhi kriteria kevalidan, kepraktisan, dan keefektifan.

Berdasarkan uraian di atas maka tujuan penelitian ini adalah menghasilkan perangkat pembelajaran IPA topik tekanan pada zat cair berorientasi inkuiri terbimbing untuk melatihkan keterampilan proses sains dan pemahaman konsep siswa SMP yang valid, praktis, dan efektif. Kevalidan dapat dilihat dari hasil validasi dan keterbacaan perangkat pembelajaran. Kepraktisan dapat dilihat dari keterlaksanaan RPP, aktivitas siswa, dan hambatan-hambatan selama proses pembelajaran. Keefektifan dapat dilihat dari hasil belajar siswa dan respon peserta terhadap perangkat dan kegiatan pembelajaran.

\section{METODE PENELITIAN}

Jenis penelitian ini adalah penelitian dan pengembangan (research and development) karena dikembangkan beberapa perangkat pembelajaran yang meliputi: rencana pelaksanaan pembelajaran (RPP), lembar kegiatan siswa (LKS), buku siswa, dan soal tes yang terdiri atas tes keterampilan proses sains (TKPS) dan tes pemahaman konsep (TPK). Subjek penelitian ini 
adalah perangkat pembelajaran IPA topik tekanan pada zat cair berorientasi inkuiri terbimbing yang dikembangkan oleh peneliti dan telah diujicobakan sebelumnya (uji coba I) di SMP Negeri 7 Bontang terhadap 10 siswa kelas VIII tahun ajaran 2013/2014. Perangkat tersebut selanjutnya diujicobakan pada uji coba II (uji lapang) pada 24 siswa di sekolah yang sama pada tahun ajaran 2014/2015.

Perangkat pembelajaran dikembangkan dengan menggunakan four $D$ models atau model 4-D (Thiagarajan, Semmel, dan Semmel: 1974) yang terdiri atas empat tahap, yaitu pendefinisian (Define), perancangan (Design), pengembangan (Develop), dan penyebaran (Disseminate). Hasil pengembangan hanya diterapkan pada tempat penelitian sehingga pengembangan perangkat yang dilakukan hanya sampai pada tahap pengembangan. Perangkat yang telah dikembangkan kemudian diujicobakan dalam pembelajaran di kelas menggunakan one group pretestposttest design (Tuckman, 1978), yang digambarkan dengan bagan sebagai berikut:

Keterangan:

\begin{tabular}{|lll|}
\hline $\mathrm{O}_{1}$ & $\mathrm{X}$ & $\mathrm{O}_{2}$ \\
\hline
\end{tabular}

$\mathrm{X}=$ Tindakan atau perlakuan dimana siswaadalah sebagai sasaran dalam uji coba pengembangan perangkat pembelajaran model inkuiri terbimbing

$\mathrm{O}_{1}=$ Hasil observasi sebelum tindakan (pretest)

$\mathrm{O}_{2}=$ Hasil observasi sesudah tindakan (posttest)

Pada penelitian ini, terdapat beberapa teknik pengumpulan data yang dilakukan peneliti, antara lain:

1. Validitas perangkat pembelajaran, yaitu validasi perangkat pembelajaran dilakukan oleh dua orang validator (ahli di bidangnya) yang sebelumnya diberikan lembar check list validitas untuk menilai perangkat pembelajaran yang telah dikembangkan. Perangkat pembelajaran yang divalidasi meliputi: RPP, LKS, Buku Siswa, soal TKPS, dan soal TPK. Selain validasi dilakukan pula validasi keterbacaan buku siswa. Data tingkat keterbacaan buku siswa diperoleh dengan cara memberikan lembar isian keterbacaan kepada siswa, di mana pada lembar tersebut dilesapkan beberapa kata yang selanjutnya dilengkapi siswa.

2. Observasi, yaitu melakukan pengamatan secara langsung ke objek penelitian untuk melihat dari dekat kegiatan yang dilakukan. Observasi dilakukan untuk mengumpulkan data selama proses pembelajaran berupa keterlaksanaan pembelajaran sesuai RPP yang telah dikembangkan, aktivitas siswa, dan hambatanhambatan selama proses pembelajaran. Kegiatan ini dilakukan oleh dua orang pengamat dengan menggunakan lembar instrumen yang sama untuk mengamati variabel yang sama.

3. Tes, yaitu pemberian soal kepada siswa sebelum dan setelah pembelajaran dilaksanakan untuk mengetahui peningkatan hasil belajar siswa.

4. Angket, digunakan untuk mengumpulkan data tentang respon siswa terhadap pembelajaran dengan cara memberi tanda ceklis pada setiap pertanyaan yang disediakan pada lembar angket.

5. Dokumentasi, untuk mencari data yang diperlukan seperti nama siswa sebagai subjek penelitian, nilai hasil belajar sebelum dan sesudah pembelajaran, foto-foto saat pembelajaran, dan data pendukung lainnya yang mungkin diperlukan.

Analisis data yang digunakan dalam penelitian ini menggunakan teknik kuantitatif dan deskriptif kualitatif. Adapun data-data hasil penelitian yang akan dianalisis antara lain:

\section{A. Analisis Validitas Perangkat Pembelajaran}

Validasi perangkat pembelajaran dilakukan oleh dua orang yang ahli di bidangnya. Analisa hasil data validasi perangkat pembelajaran disajikan dalam skala penilaian sesuai dengan kriteria yang ditentukan. Hasil skor yang diperoleh dari validator selanjutnya dihitung rata-rata dan dikonversi menggunakan ketentuan pada Tabel 1 .

Tabel 1. Kategori Penilaian Validasi Perangkat Pembelajaran

\begin{tabular}{|c|c|l|}
\hline $\begin{array}{c}\text { Interval } \\
\text { Skor }\end{array}$ & $\begin{array}{c}\text { Kategori } \\
\text { Penilaian }\end{array}$ & \multicolumn{1}{|c|}{ Keterangan } \\
\hline $3,6 \leq \mathrm{P} \leq 4$ & Sangat Valid & $\begin{array}{l}\text { Dapat digunakan tanpa } \\
\text { revisi }\end{array}$ \\
\hline $2,6 \leq \mathrm{P} \leq 3,5$ & Valid & $\begin{array}{l}\text { Dapat digunakan } \\
\text { dengan sedikit revisi }\end{array}$ \\
\hline $1,6 \leq \mathrm{P} \leq 2,5$ & Kurang Valid & $\begin{array}{l}\text { Dapat digunakan } \\
\text { dengan banyak revisi }\end{array}$ \\
\hline $1,0 \leq \mathrm{P} \leq 1,5$ & Tidak Valid & $\begin{array}{l}\text { Belum dapat digunakan } \\
\text { dan masih memerlukan } \\
\text { konsultasi }\end{array}$ \\
\hline
\end{tabular}

(Ratumanan dan Laurens, 2006)

\section{B. Analisis Keterbacaan Buku Siswa}

Uji keterbacaan buku siswa dilakukan untuk mengetahui kemudahan buku siswa yang digunakan dalam proses pembelajaran. Teknik yang digunakan yaitu melesapkan beberapa kata dalam satu kalimat pada lembar keterbacaan buku siswa namun tidak mengubah makna dari kalimat tersebut. Kriteria tingkat keterbacaan buku siswa mengacu pada Tabel 2, sedangkan rumus yang digunakan untuk memperoleh skor keterbacaan adalah:

$$
k_{B}=\frac{k}{\sum k} \times 100 \%
$$

Keterangan:

$k_{B}=$ persentase keterbacaan

$k \quad=$ jumlah kata yang diisi benar

$\sum k=$ jumlah seluruh kata yang harus diisi 
Tabel 2.Tingkat Keterbacaan Buku Siswa

\begin{tabular}{|c|c|c|}
\hline $\begin{array}{c}\text { Derajat/level/ } \\
\text { tingkat }\end{array}$ & Interval nilai & Kategori \\
\hline Level bebas & Diatas $60 \%$ & $\begin{array}{c}\text { Materi mudah untuk } \\
\text { pembelajaran }\end{array}$ \\
\hline $\begin{array}{c}\text { Level } \\
\text { pembelajaran }\end{array}$ & $40 \%-60 \%$ & $\begin{array}{c}\text { Materi tepat untuk } \\
\text { pembelajaran }\end{array}$ \\
\hline Level tekanan & Di bawah $40 \%$ & $\begin{array}{c}\text { Materi sulit untuk } \\
\text { pembelajaran }\end{array}$ \\
\hline
\end{tabular}

(Taylor, 1953)

\section{Analisis Keterlaksanaan RPP}

Keterlaksanaan RPP diamati oleh dua orang pengamat, di mana pengamat-pengamat tersebut menyaksikan secara langsung dan memberikan penilaian terhadap keterlaksanaan fase-fase pembelajaran yang tercantum dalam skenario RPP yang dikembangkan. Keterlaksanaan pembelajaran dianalisis dengan cara kuantitatif yaitu dengan merata-rata skor seluruh komponen pada setiap pertemuan. Hasil skor rata-rata dideskripsikan sesuai pada Tabel 3 berikut.

Tabel 3. Kategori Pengamatan Keterlaksanaan RPP

\begin{tabular}{|c|c|}
\hline Rentang Skor & Kesimpulan \\
\hline $1,00-1,49$ & Tidak baik \\
\hline $1,50-2,49$ & Kurang baik \\
\hline $2,50-3,49$ & Cukup Baik \\
\hline $3,50-4,00$ & Baik \\
\hline
\end{tabular}

(Ratumanan dan Laurens, 2006)

\section{Analisis Aktivitas Siswa}

Aktivitas siswa adalah frekuensi kegiatan yang dilakukan siswa selama proses pembelajaran berlangsung. Pengamatan aktivitas siswa dilakukan oleh dua orang pengamat. Aktivitas siswa dianalisis dengan deskriptif kuantitatif dengan menggunakan rumus percentage of agreement sebagai berikut:

$$
P=\frac{\sum A}{\sum N} \times 100 \%
$$

$\mathrm{P} \quad=$ Persentase aktivitas siswa

$\sum A=$ Jumlah aktivitas

$\sum N=$ Jumlah keseluruhan aktivitas

\section{E. Analisis Hambatan-hambatan Proses Pembelajaran}

Temuan hambatan-hambatan selama proses pembelajaran berlangsung dianalisis secara deskriptif kualitatif melalui diskusi antara pengamat dan peneliti. Hasil diskusi kemudian dicari solusinya untuk mengatasi hambatan-hambatan yang ditemukan.

\section{F. Analisis Tes Keterampilan Proses Sains dan Tes Pemahaman Konsep}

Tes keterampilan proses sains dan pemahaman konsep dilakukan sebelum pembelajaran (pretest) dan setelah pembelajaran (posttest). Hasil tes yang diperoleh dianalisis secara kuantitatif. Siswa dinyatakan tuntas apabila memperoleh nilai $\geq 67$. Rumus yang digunakan
Keterangan:

untuk mengetahui nilai tes keterampilan proses sains adalah:

Nilai $=\frac{\text { Jumlah skor yang diperoleh siswa }}{\text { Jumlah skor maksimum }} \times 100$

sedangkan nilai tes pemahaman konsep diperoleh dengan menggunakan rumus berikut.

Nilai $=\frac{\text { Jumlah soal yang dijawab benar oleh siswa }}{\text { Jumlah seluruh soal }} \times 100$

Hasil tes selanjutnya dianalisis menggunakan $\mathrm{N}$-gain $(g)$ untuk mengetahui tingkat keefektifan pembelajaran yang dilaksanakan dengan menggunakan rumus berikut.

$$
(g)=\frac{\text { Nilai } \text { posttest-Nilai } \text { pretest }}{\text { Nilai maksimal-Nilai } \text { pretest }}
$$

Kriteria N-Gain menurut Hake (1998) terbagi atas 3 tingkatan, yakni:

1) Pembelajaran dengan "gain-tinggi", jika (g) $\geq 0,7$;

2) Pembelajaran dengan "gain-sedang", jika $0,7 \geq$ (g) $\geq 0,3$

3) Pembelajaran dengan "gain-rendah", jika (g) $<0,3$.

\section{G. Analisis Respon Siswa}

Data respon siswa diperoleh dari angket respon siswa terhadap perangkat dan kegiatan pembelajaran, selanjutnya dianalisis dengan menggunakan deskriptif kuantitatif. Secara matematis dapat ditulis sebagai berikut:

$$
P=\frac{\sum K}{\sum N} \times 100 \%
$$

Keterangan:

$\mathrm{P} \quad=$ Persentase respon siswa

$\sum K=$ Jumlah respon yang siswa berikan

$\sum N=$ Jumlah seluruh siswa

\section{HASIL PENELITIAN DAN DISKKUSI}

\section{A. Validitas Perangkat Pembelajaran}

Hasil penilaian perangkat pembelajaran yang telah dikembangkan oleh peneliti disajikan pada Grafik 1.

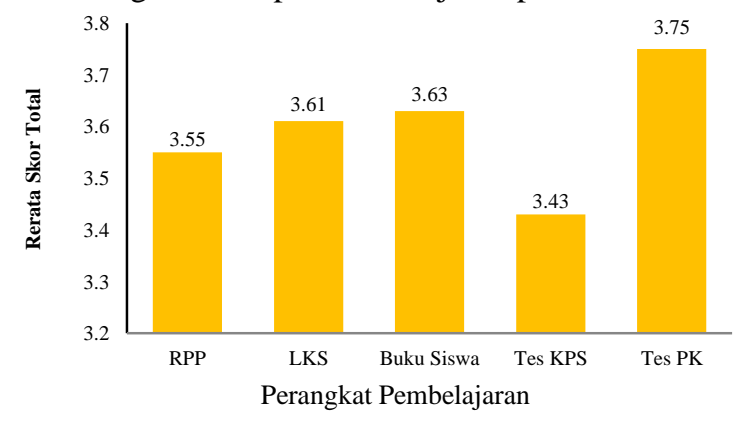

Grafik 1. Hasil Validasi Perangkat Pembelajaran

Hasil validasi pada Gambar 1 menunjukkan bahwa perangkat yang dikembangkan valid untuk digunakan dalam pembelajaran. Perolehan skor validasi yang baik ini diperoleh karena peneliti telah berupaya dengan sungguh-sungguh melalui konsultasi kepada pembimbing dan melakukan revisi atas saran-saran yang diberikan selama pengembangan perangkat,

Pada Zat Cair Berorientasi Inkuiri Terbimbing untuk.. 
mempelajari literatur yang mendukung, dan revisi yang dilakukan peneliti berdasarkan masukan dan saran dari para validator.

\section{B. Keterbacaan Buku Siswa}

Hasil tingkat keterbacaan buku siswa dengan teknik disajikan pada Tabel 4.

Tabel 4. Tingkat Keterbacaan Buku Siswa

\begin{tabular}{|l|c|}
\hline $\begin{array}{c}\text { Kelengkapan Keterbacaan } \\
\text { Buku Siswa }\end{array}$ & Skor dan Keterangan \\
\hline Jumlah siswa yang diuji & 24 \\
\hline Jumlah kata yang dilesapkan & 20 \\
\hline Persentase keterbacaan & $77,29 \%$ \\
\hline Kategori & $\begin{array}{c}\text { Materi mudah untuk } \\
\text { pembelajaran }\end{array}$ \\
\hline
\end{tabular}

Tabel 4 menunjukkan bahwa buku siswa mudah dipahami oleh siswa dan dapat digunakan sebagai rujukan atau panduan dalam pembelajaran. Hal tersebut juga dinyatakan oleh Nurlaili (2011) bahwa keterbacaan wacana memberikan hasil yang baik bagi pembaca karena pembaca mendapatkan sebuah bacaan yang dapat dibaca dan dipahaminya. Perolehan hasil keterbacaan buku siswa yang baik ini tidak lepas dari masukan dan saran dari pembimbing dan validator serta upaya terbaik peneliti dalam mengembangkan buku. Peneliti berusaha menyuguhkan kalimat-kalimat yang sederhana, tidak terlalu panjang, penggunaan jenis huruf dan spasi yang memungkinkan materi dapat dibaca dengan jelas oleh siswa, dan penggunaan warna dan gambar agar tampilan buku menjadi menarik bagi siswa.

\section{Keterlaksanaan RPP}

Rencana Pelaksanaan Pembelajaran dikembangkan dengan menggunakan model inkuiri terbimbing untuk tiga kali pertemuan. Rata-rata skor penilaian keterlaksanaan RPP pada setiap pertemuan disajikan pada Grafik 2.

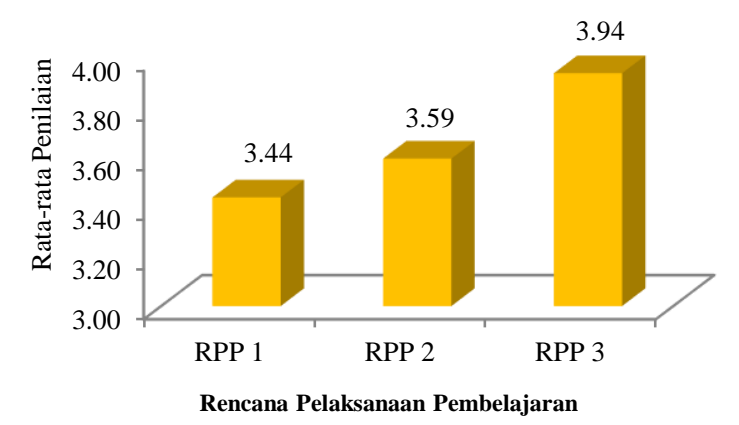

Grafik 2. Diagram Keterlaksanaan RPP

Langkah- langkah kegiatan yang terdapat pada RPP dapat dilaksanakan seluruhnya dengan baik. Rata-rata penilaian keterlaksanaan RPP sebesar 3,66, dengan kategori baik. Rata-rata reliabilitas sebesar $98 \%$, artinya instrumen dikatakan reliabel (Borich, 1994). Secara umum rata-rata penilaian keterlaksanaan RPP mengalami peningkatan untuk tiap pertemuannya seperti yang ditunjukkan pada Gambar 2. Peningkatan penilaian ini diperoleh karena upaya yang dilakukan guru untuk melakukan refleksi kegiatan pembelajaran yang telah dilaksanakan. Refleksi ini membantu guru melihat kekurangan atau hambatan dalam pelaksanaan pembelajaran dan memperbaikinya untuk pertemuan selanjutnya.

\section{Aktivitas Siswa}

Aktivitas siswa diamati oleh dua orang pengamat, yaitu: 1) mendengarkan penjelasan guru atau teman, 2) membaca bahan ajar, 3) bertanya pada guru untuk bimbingan, 4) merumuskan masalah, 5) merumuskan hipotesis, 6) mengidentifikasi variabel, 7) melaksanakan eksperimen, 8) berdiskusi dalam menganalisis data, 9) menyimpulkan dan mempresentasikan hasil eksperimen, 10) mengerjakan soal peningkatan pemahaman, dan 11) perilaku yang tidak relevan (melakukan percakapan dan tindakan yang tidak relevan dengan kegiatan belajar). Hasil pengamatan aktivitas siswa disajikan pada Grafik 2 berikut.

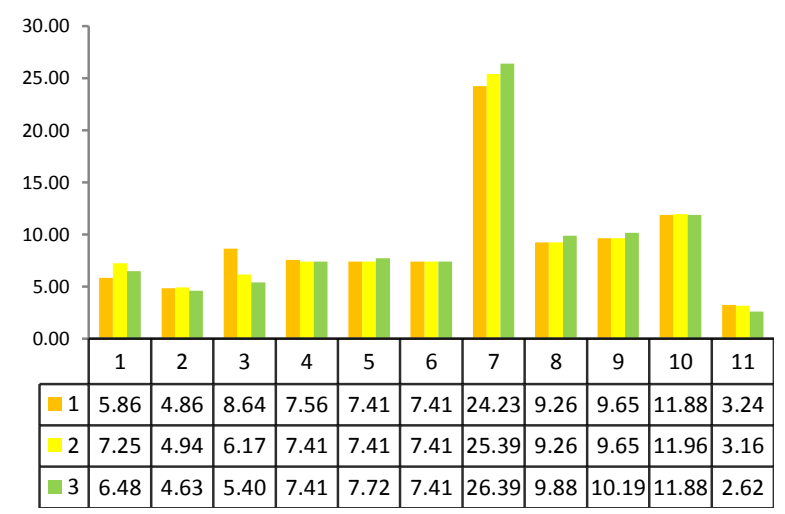

Grafik 3. Aktivitas siswa

Aktivitas pada Gambar 3 menunjukkan bahwa pembelajaran dengan model inkuiri terbimbing berpusat pada siswa. Pembelajaran model inkuiri terbimbing akan mendorong siswa untuk membangun sendiri pengetahuan dalam benaknya dengan bantuan guru dan didorong untuk berfikir kritis melalui keterlibatan aktif yang memungkinkan mereka menemukan fakta dan konsep bagi diri mereka sendiri sehingga fakta dan konsep tersebut menjadi bermakna bagi mereka (Kuhlthau, et al; Wenning, 2007). Peranan guru dalam pembelajaran menjadi fasilitator dan membimbing siswa yang masih kesulitan dalam melakukan penyelidikan. Siswa aktif dalam berlatih keterampilan proses sains, aktivitas yang dominan sebagaimana disajikan pada Gambar 3 adalah melaksanakan eksperimen dengan rata-rata $25,33 \%$. Hal ini sesuai dengan tahapan yang direncanakan dalam rencana pembelajaran model inkuiri terbimbing untuk membelajarkan siswa dengan mengalami secara langsung dalam penyelidikan agar informasi dapat diperoleh dan diingat dengan baik. 
Aktivitas diskusi yang dilakukan siswa menunjukkan bahwa siswa dalam kegiatan pembelajaran berada di lingkungan sosial, mereka belajar melalui interaksi dengan orang lain di sekitar mereka. Vigotsky berpendapat bahwa perkembangan proses hidup bergantung pada interaksi sosial dan pembelajaran sosial berperan penting untuk perkembangan kognitif (Slavin, 2011). Perilaku yang tidak relevan teramati rata-rata sebesar 3,01\% dari seluruh waktu yang digunakan untuk pembelajaran, hal ini menunjukkan minat siswa untuk mengikuti pembelajaran cukup tinggi.

\section{E. Hambatan-hambatan selama Pembelajaran}

Terdapat beberapa hambatan yang muncul saat pembelajaran, namun hambatan-hambatan yang muncul dapat diatasi dengan sangat baik oleh peneliti sehingga kegiatan pembelajaran tidak terganggu dan dapat berjalan lancar. Kendala yang ditemui adalah masalah waktu kegiatan pembelajaran yang melebihi alokasi waktu yang telah ditentukan. Hal ini disebabkan siswa menuntut kemampuan siswa dalam menggunakan keterampilan proses sains. Siswa yang belum pernah menggunakan alat ukur berupa neraca pegas juga menjadi salah satu hambatan, penjelasan yang diberikan guru mengenai penggunaan alat ukur menjadi solusi.

\section{F. Keterampilan Proses Sains}

Data keterampilan proses sains siswa diperoleh dari hasil pretest dan posttest. Keterampilan proses sains yang dimaksud terdiri dari: 1) merumuskan masalah, 2) merumuskan hipotesis, 3) mengidentifikasi variabel, 4) menganalisa data, dan 5) merumuskan kesimpulan. Hasil tes keterampilan proses sains siswa disajikan pada Tabel 5 berikut.

Tabel 5. Hasil Tes Keterampilan Proses Sains Siswa

\begin{tabular}{|c|c|c|c|c|c|c|}
\hline \multirow{2}{*}{ Siswa } & \multicolumn{2}{|c|}{ Pretest } & \multicolumn{2}{c|}{ Posttest } & \multicolumn{2}{|c|}{ N-gain } \\
\cline { 2 - 7 } & Nilai & Ket & Nilai & Ket & Skor & Kategori \\
\hline 1 & 24 & BT & 82 & T & 0,77 & gain-tinggi \\
\hline 2 & 59 & BT & 94 & T & 0,86 & gain-tinggi \\
\hline 3 & 35 & BT & 88 & T & 0,82 & gain-tinggi \\
\hline 4 & 29 & BT & 82 & T & 0,75 & gain-tinggi \\
\hline 5 & 41 & BT & 88 & T & 0,80 & gain-tinggi \\
\hline 6 & 24 & BT & 76 & T & 0,69 & gain-sedang \\
\hline 7 & 24 & BT & 82 & T & 0,77 & gain-tinggi \\
\hline 8 & 59 & BT & 82 & T & 0,57 & gain-sedang \\
\hline 9 & 59 & BT & 94 & T & 0,86 & gain-tinggi \\
\hline 10 & 29 & BT & 94 & T & 0,92 & gain-tinggi \\
\hline 11 & 24 & BT & 88 & T & 0,85 & gain-tinggi \\
\hline 12 & 24 & BT & 88 & T & 0,85 & gain-tinggi \\
\hline 13 & 47 & BT & 94 & T & 0,89 & gain-tinggi \\
\hline 14 & 47 & BT & 94 & T & 0,89 & gain-tinggi \\
\hline
\end{tabular}
belum terbiasa mengerjakan LKS berbasis inkuiri yang

\begin{tabular}{|c|c|c|c|c|c|c|}
\hline \multirow{2}{*}{ Siswa } & \multicolumn{2}{|c|}{ Pretest } & \multicolumn{2}{c|}{ Posttest } & \multicolumn{2}{|c|}{ N-gain } \\
\cline { 2 - 7 } & Nilai & Ket & Nilai & Ket & Skor & Kategori \\
\hline 15 & 41 & $\mathrm{BT}$ & 94 & $\mathrm{~T}$ & 0,90 & gain-tinggi \\
\hline 16 & 18 & $\mathrm{BT}$ & 82 & $\mathrm{~T}$ & 0,79 & gain-tinggi \\
\hline 17 & 47 & $\mathrm{BT}$ & 94 & $\mathrm{~T}$ & 0,89 & gain-tinggi \\
\hline 18 & 29 & $\mathrm{BT}$ & 94 & $\mathrm{~T}$ & 0,92 & gain-tinggi \\
\hline 19 & 41 & $\mathrm{BT}$ & 76 & $\mathrm{~T}$ & 0,60 & gain-sedang \\
\hline 20 & 29 & $\mathrm{BT}$ & 88 & $\mathrm{~T}$ & 0,83 & gain-tinggi \\
\hline 21 & 35 & $\mathrm{BT}$ & 94 & $\mathrm{~T}$ & 0,91 & gain-tinggi \\
\hline 22 & 24 & $\mathrm{BT}$ & 94 & $\mathrm{~T}$ & 0,92 & gain-tinggi \\
\hline 23 & 59 & $\mathrm{BT}$ & 88 & $\mathrm{~T}$ & 0,71 & gain-tinggi \\
\hline 24 & 29 & $\mathrm{BT}$ & 94 & $\mathrm{~T}$ & 0,92 & gain-tinggi \\
\hline $\begin{array}{c}\text { Rata } \\
\text {-rata }\end{array}$ & 36,52 & & 88,73 & & 0,82 & gain-tinggi \\
\hline
\end{tabular}

BT $=$ Belum Tuntas, $\mathrm{T}=$ Tuntas

Tabel 5 menunjukkan bahwa setiap siswa mengalami peningkatan hasil belajar keterampilan proses sains yang signifikan. Hal yang mendukung ketercapaian hasil yang lebih baik adalah keterlaksanaan tahapan pembelajaran yang melatihkan keterampilan proses sains kepada siswa melalui kegiatan eksperimen selama tiga kali pertemuan. Pada pertemuan awal guru memodelkan terlebih dahulu bagaimana melakukan eksperimen dan menggunakan keterampilan proses. Hal ini dilakukan untuk memberikan gambaran kepada siswa mengenai kegiatan yang akan dilakukan.

Interaksi antar siswa dalam kegiatan penyelidikan memberikan kesempatan teman yang lebih kompeten untuk membantu teman lain sehingga membantu melatihkan keterampilan proses siswa. Hal ini sesuai dengan teori yang dikemukakan oleh Vygotsky bahwa pengajaran pribadi oleh teman sebaya yang lebih kompeten dapat berjalan efektif meningkatkan pertumbuhan pada zona perkembangan proksimal, demikian pula interaksi di sekitar tugas-tugas yang rumit. Aktivitas-aktivitas yang dominan dilakukan siswa menunjukkan siswa aktif dalam berlatih keterampilan proses selama mengikuti proses pembelajaran mendukung ketercapaian hasil keterampilan proses siswa yang lebih baik. Respon positif siswa terhadap suasana pembelajaran yang menyenangkan membuat siswa berminat untuk mengikuti pembelajaran selanjutnya dengan model inkuiri terbimbing untuk melatihkan keterampilan proses. Namun, siswa masih memerlukan latihan secara berkelanjutan agar siswa terbiasa untuk menggunakan keterampilan proses dalam memecahkan masalah-masalah pada pembelajaran.

Hasil penelitian ini relevan dengan penelitian Khotimah (2013) yang menunjukkan bahwa perangkat pembelajaran yang dikembangkan dengan pembelajaran inkuiri terbimbing efektif untuk melatihkan keterampilan proses siswa. Penelitian lain yang 
mendukung penelitian ini adalah penelitian Saputra, Sri, dan Slamet (2012) yang menunjukkan bahwa melalui penerapan guided inquiry keterampilan proses sains siswa mengalami peningkatan. Kegiatan pembelajaran seperti yang dilakukan dalam penelitian ini diharapkan dapat memenuhi harapan dari Kurikulum 2013 yaitu adanya peningkatan dan keseimbangan antara kemampuan untuk menjadi manusia yang baik dan manusia yang memiliki keterampilan dan pengetahuan untuk hidup secara layak dari siswa.

\section{G. Pemahaman Konsep}

Pemahaman konsep siswa dapat diketahui melalui tes pengetahuan terhadap materi tekanan pada zat cair yang diberikan selama pembelajaran. Pemahaman konsep yang digunakan mengacu pada tingkat berpikir domain kognitif Bloom dalam teori yang telah direvisi (Anderson dan Krathwool, 2001). Tes ini dilakukan dua kali yaitu sebelum pembelajaran (pretest) dan sesudah pembelajaran (posttest) di mana soal yang diberikan mempunyai tingkat kesulitan dan materi yang sama. Hasil tes pemahaman konsep siswa disajikan pada Tabel 6.

Tabel 6. Hasil Tes Pemahaman Konsep Siswa

\begin{tabular}{|c|c|c|c|c|c|c|}
\hline \multirow{2}{*}{ Siswa } & \multicolumn{2}{|c|}{ Pretest } & \multicolumn{2}{|c|}{ Posttest } & \multicolumn{2}{|c|}{$\mathrm{N}$-gain } \\
\hline & Nilai & Ket & Nilai & Ket & Skor & Kategori \\
\hline 1 & 33 & BT & 80 & $\mathrm{~T}$ & 0,70 & gain-tinggi \\
\hline 2 & 53 & BT & 100 & $\mathrm{~T}$ & 1,00 & gain-tinggi \\
\hline 3 & 47 & BT & 87 & $\mathrm{~T}$ & 0,75 & gain-tinggi \\
\hline 4 & 40 & BT & 73 & $\mathrm{~T}$ & 0,56 & gain-sedang \\
\hline 5 & 27 & BT & 80 & $\mathrm{~T}$ & 0,73 & gain-tinggi \\
\hline 6 & 40 & BT & 67 & $\mathrm{~T}$ & 0,44 & gain-sedang \\
\hline 7 & 27 & BT & 87 & $\mathrm{~T}$ & 0,82 & gain-tinggi \\
\hline 8 & 40 & BT & 93 & $\mathrm{~T}$ & 0,89 & gain-tinggi \\
\hline 9 & 20 & BT & 87 & $\mathrm{~T}$ & 0,83 & gain-tinggi \\
\hline 10 & 27 & BT & 80 & $\mathrm{~T}$ & 0,73 & gain-tinggi \\
\hline 11 & 27 & BT & 87 & $\mathrm{~T}$ & 0,82 & gain-tinggi \\
\hline 12 & 40 & BT & 80 & $\mathrm{~T}$ & 0,67 & gain-sedang \\
\hline 13 & 47 & BT & 93 & $\mathrm{~T}$ & 0,88 & gain-tinggi \\
\hline 14 & 20 & BT & 80 & $\mathrm{~T}$ & 0,75 & gain-tinggi \\
\hline 15 & 40 & BT & 93 & $\mathrm{~T}$ & 0,89 & gain-tinggi \\
\hline 16 & 33 & BT & 80 & $\mathrm{~T}$ & 0,70 & gain-tinggi \\
\hline 17 & 27 & BT & 73 & $\mathrm{~T}$ & 0,64 & gain-sedang \\
\hline 18 & 33 & BT & 60 & BT & 0,40 & gain-sedang \\
\hline 19 & 47 & BT & 73 & $\mathrm{~T}$ & 0,50 & gain-sedang \\
\hline 20 & 20 & BT & 80 & $\mathrm{~T}$ & 0,75 & gain-tinggi \\
\hline 21 & 47 & BT & 80 & $\mathrm{~T}$ & 0,63 & gain-sedang \\
\hline 22 & 33 & BT & 100 & $\mathrm{~T}$ & 1,00 & gain-tinggi \\
\hline 23 & 53 & BT & 87 & $\mathrm{~T}$ & 0,71 & gain-tinggi \\
\hline 24 & 40 & BT & 93 & $\mathrm{~T}$ & 0,89 & gain-tinggi \\
\hline
\end{tabular}

\begin{tabular}{|c|c|c|c|c|c|}
$\begin{array}{c}\text { Rata- } \\
\text { rata }\end{array}$ & 35,83 & $\mathbf{8 3 , 0 6}$ & & $\mathbf{0 , 7 4}$ & gain-tinggi \\
\hline
\end{tabular}

$\mathrm{BT}=$ Belum Tuntas, $\mathrm{T}=$ Tuntas

Tabel 6 menunjukkan bahwa nilai hasil pretest dan posttest yang diperoleh siswa terlihat mengalami peningkatan, meskipun masih terdapat satu siswa yang belum tuntas pada saat posttest. Peningkatan ini diperoleh karena meningkatnya pemahaman konsep setiap siswa setelah diberikan pembelajaran dengan perangkat yang dikembangkan.

Meningkatnya pemahaman konsep siswa menunjukkan bahwa proses pembelajaran yang dilaksanakan guru berlangsung dengan baik, hal tersebut didukung oleh data keterlaksanaan RPP. Selama pembelajaran siswa diberi kesempatan untuk menemukan sendiri konsep yang dipelajari melalui eksperimen yang didalamnya terdapat keterampilan proses, mendekatkan siswa dengan sesuatu yang dapat dilihat secara nyata. Hal ini sejalan dengan teori pemrosesan informasi bahwa keterlibatan siswa secara aktif dalam pembelajaran menyebabkan penyimpanan informasi ke memori jangka panjang. Dengan demikian belajar siswa akan lebih bermakna sehingga berdampak pada daya ingat dan pemahaman siswa terhadap konsep-konsep akan lebih baik.

Buku siswa juga memiliki peranan penting terhadap peningkatan pemahaman konsep siswa, tingkat keterbacaan buku sebesar 77,29\% menjadikan materi yang disajikan pada buku siswa mudah dipahami siswa. Hal ini menjadikan buku siswa efektif untuk memandu siswa belajar baik di kelas maupun belajar mandiri. Hal tersebut diperkuat oleh respon siswa yang sangat positif terhadap kemudahan memahami komponen buku siswa dari segi bahasa materi/isi buku dan contoh-contoh soal yang disajikan. Contoh soal, latihan soal yang terdapat pada setiap sub materi dan evaluasi yang diberikan pada bagian akhir buku menjadikan buku siswa sebagai sarana untuk berlatih mengukur pemahaman terhadap konsep atau materi yang dipelajari. Rangkuman dan glosarium pada buku siswa membantu siswa mengingat konsep-konsep esensial dan definisi secara mudah karena disajikan secara sistematis.

Berdasarkan data hasil tes pemahaman konsep diketahui bahwa terdapat 1 orang siswa yang belum tuntas dan memiliki gain score 0,40. Ketidaktuntasan siswa juga mengindikasikan bahwa tidak semua siswa memiliki kecepatan yang sama dalam membangun pengetahuan. Siswa tersebut memerlukan bimbingan atau tambahan waktu dalam belajar untuk dapat memahami konsep yang dipelajari dibandingkan dengan siswa lainnya. Solusi yang memungkinkan untuk diterapkan dalam rangka mencapai ketuntasan adalah guru diharapkan lebih meningkatkan kemampuan dalam mengelola pembelajaran serta lebih 
banyak memberikan latihan-latihan soal agar siswa terbiasa dengan soal IPA dan memberikan remedial.

Hasil penelitian ini mendukung penelitian yang telah dilakukan oleh Chrisnawati (2013) yang menyatakan bahwa model pembelajaran inkuiri terbimbing efektif untuk melatihkan keterampilan proses sains siswa dan meningkatkan pemahaman konsep siswa. Penelitian lain yang relevan dengan penelitian ini adalah penelitian yang dilakukan Sudarman (2012) bahwa penggunaan model inkuiri terbimbing menunjukkan peningkatan pemahaman konsep dan kinerja ilmiah siswa yang lebih baik daripada penggunaan pembelajaran langsung.

\section{H. Respon Siswa}

Respon siswa merupakan tanggapan siswa terhadap perangkat pembelajaran yang dikembangkan dan proses pembelajaran di kelas. Data respon siswa diperoleh melalui angket, diasumsikan bahwa siswa memberikan informasi secara jujur terhadap pertanyaan-pertanyaan yang diajukan dalam angket. Hasil respon siswa disajikan pada Tabel 11.

Hasil Respon Siswa

\begin{tabular}{|c|l|c|}
\hline No & \multicolumn{1}{|c|}{ Kategori Respon } & Persentase \\
\hline 1 & $\begin{array}{l}\text { Ketertarikan terhadap perangkat dan } \\
\text { model pembelajaran }\end{array}$ & 99,31 \\
\hline 2 & $\begin{array}{l}\text { Kebaruan perangkat dan model } \\
\text { pembelajaran }\end{array}$ & 96,67 \\
\hline 3 & $\begin{array}{l}\text { Kemudahan memahami perangkat } \\
\text { pembelajaran }\end{array}$ & 95,83 \\
\hline 4 & Kebaruan keterampilan proses sains & 92,19 \\
\hline 5 & $\begin{array}{l}\text { Kemudahan mempelajari keterampilan } \\
\text { proses sains }\end{array}$ & 91,15 \\
\hline 6 & $\begin{array}{l}\text { Keminatan menggunakan model inkuiri } \\
\text { terbimbing pada pembelajaran } \\
\text { selanjutnya }\end{array}$ & 100 \\
\hline 7 & $\begin{array}{l}\text { Kejelasan terhadap penjelasan dan } \\
\text { bimbingan guru selama pembelajaran }\end{array}$ & 100 \\
\hline
\end{tabular}

Respon siswa sebagaimana disajikan pada Tabel 11 menunjukkan bahwa siswa memberikan respon positif terhadap perangkat yang digunakan dan kegiatan pembelajaran. Respon positif ini mengindikasikan bahwa siswa antusias dengan pembelajaran yang disajikan. Antusias dalam pembelajran dapat memotivasi siswa untuk meningkatkan perhatian dan membuat mereka terlibat aktif dalam pengalaman pembelajaran yang menyenangkan dan bermakna (Nur, 2008). Motivasi ini yang mendorong siswa untuk melakukan aktivitas pembelajaran seperti yang teramati oleh pengamat, dengan intensitas yang cukup tinggi.

\section{KESIMPULAN}

\section{A. Simpulan}

Berdasarkan hasil analisis, diskusi hasil dan temuantemuan dalam proses pembelajaran, maka dapat disimpulkan bahwa perangkat pembelajaran IPA topik tekanan pada zat cair berorientasi inkuiri terbimbing yang dikembangkan valid, praktis, dan efektif untuk melatihkan keterampilan proses sains dan pemahaman konsep siswa SMP.

\section{B. Saran}

Berdasarkan penelitian yang telah dilakukan dan hasil yang didapat, maka saran yang dapat diberikan adalah: 1) pembelajaran dengan model inkuiri terbimbing memerlukan pengaturan waktu yang baik oleh guru selama proses pembelajaran sehingga pembelajaran dapat berlangsung sesuai dengan tujuan yang diharapkan, 2) Sebelum memulai pembelajaran dengan inkuiri terbimbing sebaiknya guru memberikan bimbingan pada waktu khusus untuk memberikan gambaran mengenai kegiatan penyelidikan, karena siswa belum sepenuhnya memahami keterampilanketerampilan proses sains. Bimbingan ini dapat berupa pemberian hand out keterampilan proses atau paparan keterampilan proses melalui power point.

\section{DAFTAR PUSTAKA}

Aktamis, H., Ergin, O., (2008). "The effect of scientific process skills education on students' scientific creativity, science attitudes and academic achievements". Asia-pacific forum on science learning and teaching. Vol. 9, Issue 1, Article 4, pp.1-21.

Anderson, L.D. dan Krathwool, D.R. (2001). A taxonomy for learning, teaching, and assessing: A revision of Bloom's Taxonomy of Educational Objectives. New York: Addison Wesley Longman, Inc.

Arends, R. (2013). Belajar untuk Mengajar Edisi 9 Buku 2. Jakarta: Salemba Humanika

Borich, Gary D. (1994). Observation skills for effective teaching ( $2^{\text {nd }} e d$.). Englewood Cliffs: Macmillan Publishing Company

Borich, G.D., and Coo, O.A. (2006). Teaching strategies that promote thinking, models and curriculum approaches. McGraw-Hills: Education Asia.

Chrisnawati, Z. (2013). Pengembangan perangkat pembelajaran inkuiri terbimbing untuk melatihkan keterampilan proses sains pada materi suhu dan kalor. (Tesis magister pendidikan tidak dipublikasikan). Universitas Negeri Surabaya.

Eggen, P.D. anda Kauchak, D.P. (1993). Strategy for teacher. Singapore: Allyn and Bacon

Gronlund, Norman E. (1981). Measurement and evaluation in teaching. New York: Macmillan Publishing Co., Inc. 
Hake, Richard R. (1998). "Interactive-engagement versus traditional methods: A six-thousandstudent survey of mechanics test data for introductory physics courses". American Journal of Physics. Vol.66 No.1 January 1998, pp. 64-74

Ibrahim, M. (2002). Pengembangan perangkat pembelajaran (pelatihan terintegrasi berbasis kompetensi guru mata pelajaran biologi). Jakarta: Depdiknas

Ibrahim, M. (2010). Dasar-dasar proses belajar mengajar. Surabaya: Unesa University Press

Kuhlthau, C.C., Maniotes L.K., Caspari A.K. (2012). Guided inquiry Design. Libraries Unlimited: Imprint $\mathrm{ABC}$

Kuhlthau, C.C. (2007). Guided Inquiry: Learning in the 21th Century. USA: Center for International Scholarship in School Libraries (CISSL)

Khotimah, K. (2013). "Pengembangan perangkat pembelajaran berdasarkan model inkuiri terbimbing dalam rangka melatihkan keterampilan proses siswa". Makalah Komprehensif. Surabaya: Universitas Negeri Surabaya.

Nieeven, Nieke. (1999). "Prototyping to reach product quality”. In Jan van den Akker, R. M. Branch, K. Gustafson, N. Nieeven \& Tjeerd Plomp (Eds). Design approaches and tools in education and training, 125-136. Dorgrecht: Kluwer Academic Publisher

Nurlaili. (2011)."Pengukuran Tingkat Keterbacaan Wacana Dalam LKS Mata Pelajaran Bahasa Indonesia Kelas 4 - 6 SD dan Keterpahamannya". Jurnal UPI. Vol. 1, pp.167 $-177$

Nur, M. (2011). Modul keterampilan-keterampilan proses sains. Disadur dari Inquiry Skill Activity Book. Pusat Sains dan Matematika Sekolah: Universitas Negeri Surabaya
Nur, M. (2008). Pengajaran berpusat kepada siswa dan pendekatan konstruktivis dalam pengajaran (edisi 5). Surabaya: PSMS Unesa

Nur, Mohamad (Editor). (1998). Proses belajar mengajar dengan metode pendekatan keterampilan proses. Surabaya: SIC

OECD. (2013). PISA 2012 Assesessment and analytical framework. Mathematics, reading, science, problem solving and financial literacy. Paris: Organization for Economic Coorperation \& Development.

Ramadhan, D. dan Wasis. (2013). “Analisis perbandingan level kognitif dan keterampilan proses sains dalam standar isi (SI), soal ujian nasional (UN), soal Trends in International Mathematics and Science Study (TIMSS), dan soal Programme For Internatioanal Student Assessment (PISSA)". Jurnal Inovasi Pendidian Fisika. Vol 02 No 01 Tahun 2013, pp. 20-25

Ratumanan, G.T., dan T, Laurens. (2006). Evaluasi hasil belajar yang relevan dengan memecahkan problematika belajar dan mengajar. Bandung: CV Alfabeta

Semiawan, C. (1990). Pendekatan keterampilan proses. Jakarta: PT. Gramedia

Sudarman, I. N. (2012). "Pengaruh pembelajaran model inkuiri terbimbing terhadap pemahaman konsep dan kinerja ilmiah siswa SMP”. Jurnal Penelitian Pascasarjana Undiksha. Vol. 2, No.1

Thiagarajan, S.D., Semmel, S. \& Semmel, M.L. 1974. Instructional development for training teacher of exceptional children. A Source Book Bloomington: Center for Inovation on Teaching the Handicap.

Wenning, C.J. (2005). "Level of inquiry; hierarchies of pedagogical practices and inquiry processes". Journal of physics teacher education. No. 3, Vol. 2. pp.3-12. 